\title{
Mineralogical and Geochemical Characteristics of Carbonate Rocks for Lime Industry in Ban Pong, Chiang Mai Province, Northern Thailand
}

\author{
Burapha Phajuy ${ }^{1}$ and Vimoltip Singtuen ${ }^{2, *}$ \\ ${ }^{I}$ Department of Geological Sciences, Faculty of Science, Chiang Mai University, \\ Chiang Mai 50200, Thailand \\ ${ }^{2}$ Department of Geotechnology, Faculty of Technology, Khon Kaen University, \\ Khon Kaen 40002, Thailand
}

('Corresponding author's e-mail: vimoltipst@gmail.com)

Received: 28 August 2020, Revised: 15 June 2021, Accepted: 28 June 2021

\begin{abstract}
One of the oldest lime manufactures in Chiang Mai Province is located in a hillside village, Ban Pong, Hang Dong District, the western part of Chiang Mai City. Villagers still have conserved traditional production methods using wood-fired kilns and the primary material selection, an Ordovician marble. There are 2 massive amounts of carbonate rocks distributed in Chiang Mai Province; Permian limestone and Ordovician marble. However, the Ordovician carbonate rocks in Ban Pong were selected to produce high-quality lime by their primitive method (man-made) for a long time. Petrographical studies suggest that the Ordovician rock samples show a granoblastic texture with a slightly foliation represents by mica flakes. They are made up mainly of calcite, with very small amounts of quartz, muscovite, talc, and opaque minerals that can be identified as marble. The mineral compositions are according to the value of $\mathrm{CaO}, \mathrm{SiO}_{2}, \mathrm{Al}_{2} \mathrm{O}_{3}, \mathrm{~K}_{2} \mathrm{O}$, and $\mathrm{Fe}_{2} \mathrm{O}_{3}$ in whole-rock analysis by XRF. The geochemical data suggest that marble in the Ban Pong area has a high $\mathrm{CaO}$ ratio and contains small amounts of muscovite, quartz, talc, and opaque minerals that may reduce the decomposition temperature during the calcination process. The Ordovician marble in Ban Pong is an appropriate raw material for traditional lime manufacture to saving energy in the production system.
\end{abstract}

Keywords: Permian limestone, Ordovician marble, Geologic material, Calcination, Chemical composition

\section{Introduction}

Lime is a product derived from the limestone calcination process until the remaining calcium oxide $(\mathrm{CaO})$ and has a lump character and white powder, and its condition is alkaline when dissolving [1]. The lime has much usefulness, including in agriculture, construction, and industry. Lime in agriculture is used for soil improvements in vegetable plots and plant orchards that are clay soil, acid soil, and germs [1]. Due to the cation exchange between lime and problem soil, plants will absorb advantage elements readily. The ion charges are commonly found in the soil are $\mathrm{Al}^{3+}, \mathrm{Mg}^{2+}, \mathrm{K}^{+}, \mathrm{H}^{+}, \mathrm{Na}^{+}, \mathrm{Li}^{+}\left(\mathrm{SO}_{4}\right)^{2-},(\mathrm{PO} 4) 3^{-},\left(\mathrm{NO}_{3}\right)^{-}$ [2].

Moreover, lime is often used to treat water in ponds, watercourses, and agricultural wastewater, especially efficiently helps reduce the acidity of water resources from organic pollutants or sulfuric acid sources [3]. It is a mixture of plaster for a construction perspective and used as fillers in asphalt tires for road paving. In addition, lime benefits many industrial manufactories such as rubber, ceramics, paper, caustic soda, bleach, and steel [1,2].

Lime is $\mathrm{CaO}$ produced from the calcination process with high temperature at about $900{ }^{\circ} \mathrm{C}$ in theoretical temperature, but $1,350{ }^{\circ} \mathrm{C}$ in fact [4]. The temperature inside the kiln depends on the composition of raw material, type of kiln, fuel used, and excellent practical size of limestone $(4-5 \mathrm{~cm})$. The rocks and minerals derived, typically limestone (marble) and chalk, are composed primarily of calcium carbonate $\left(\mathrm{CaCO}_{3}\right)$. These rocks may be cut, crushed, pulverized, and chemically altered, especially burning (calcination) to reach $\mathrm{CO}_{2}$.

Thailand has many limestone mining areas for producing lime under the business sectors as the primary industry. They always mainly explore the potential in Permian limestone, which is distributed all 
over Thailand. However, the lime production in the Ban Pong area, Hang Dong District, Chiang Mai Province, is an ancient production of Thailand that villagers still conserve traditional methods (humanmade) and selected Ordovician rock materials. There is no definite evidence of the lime production in this area but presumably done before the Doi Suthep building in $1386 \mathrm{BC}$. The present villagers produce lime from the calcination process in their local kiln by the traditional method. In the post-mining area near their kilns/the Ban Pong village, the laborers crushed the limestone and divided them into 3 sizes to build up the efficient calcination process. The entire lime manufacturing processes in this area include geologic resource, primitive method, local kiln, containing, transportation, and commercial management controlling by local people (Figure 1).

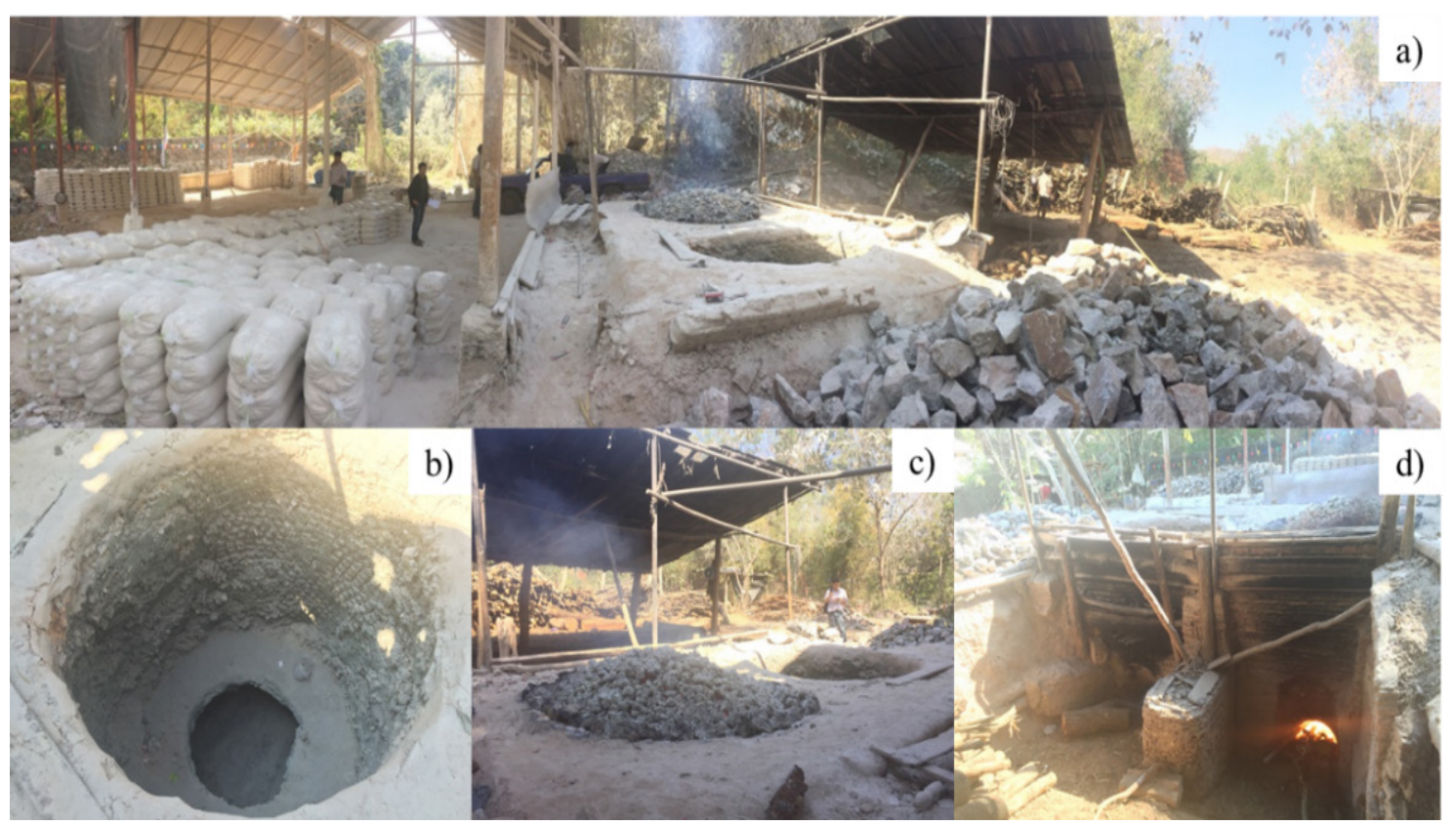

Figure 1 Lime production; a) local lime manufacture in Ban Pong, Chiang Mai Province, b) inside of kiln showing limestone and fire chambers, c) roof of the kiln covered by the restite, d) lower part of kiln showing firewood socket.

The previous geologic study of raw materials for these lime production is incomplete, lacking mineralogy and geochemical characteristics. Therefore, this work will present the mineralogy and geochemistry of these carbonate rocks related to the quality of raw material.

The high-quality lime must rely on rock quality as the raw material presented by Ordovician and Permian carbonate rocks in the Chiang Mai Basin. The reason why local people use only Ordovician rocks in their method is an inspiration for our study. Although, there are many geochemistry data of carbonate resources in Thailand [5,6], excluding Ordovician rocks in the Chiang Mai Basin. This study interprets the carbonate rocks for lime in the Ban Pong area and compares them with other carbonate rocks. The researchers divide the outcrops into 3 areas according to the location of raw materials for lithology, petrography, and geochemistry studies (Figure 2). 

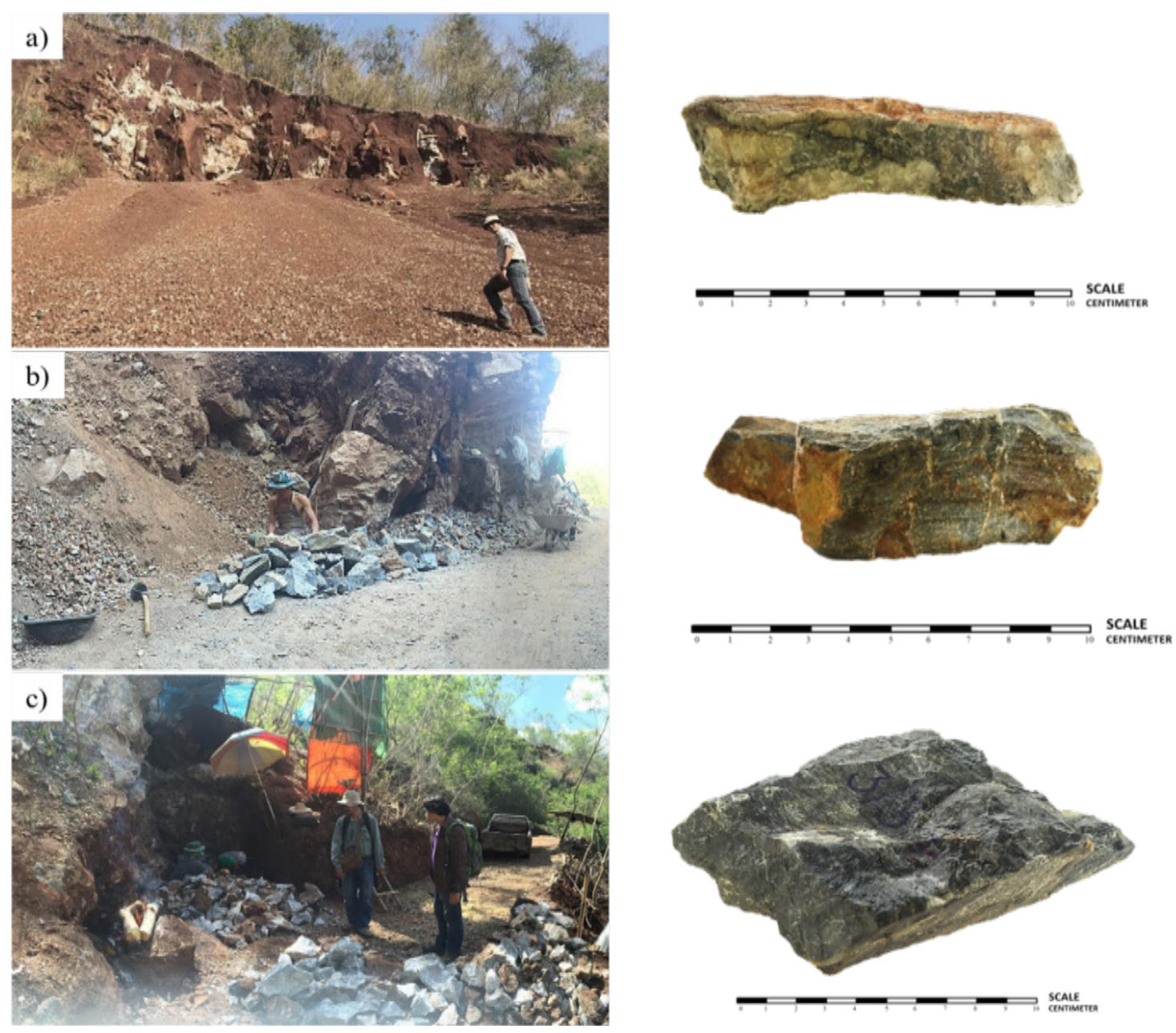

Figure 2 Limestone resources in Ban Pong, Chiang Mai Province; a) very steep cliff area, b) post-mining area c) gentle slope cliff area.

\section{Geological data}

The study area is located in Ban Pong Sub-District, Hang Dong District, Chiang Mai Province. The lime kiln's location is $18^{\circ} 44^{\prime} 58.4^{\prime \prime}$ north and $98^{\circ} 53^{\prime} 00.7^{\prime \prime}$ east, while the limestone quarry is located at latitude $18^{\circ} 45^{\prime} 43.7^{\prime \prime}$ north and longitude $98^{\circ} 51^{\prime} 58.5^{\prime \prime}$ east. The stream pattern of this area is the braided stream and flows into the Chiang Mai basin in the western part. The limestone quarry is approximately 450 meters above the mean sea level and has a steep terrain with a westward slope (Figure 3a). The foothill in the southeastern flank of the quarry is far from community settlement (approximately 5 kilometers), where the lime kilns are scattered in many places (Figure 3b).

The limestone quarry is covered by the Ordovician rocks (Figure 3c), which comprised limestone, shale, marble, and stylolite and argillaceous bands $[9,10]$. This area has a sizeable reverse fault at the boundary of Precambrian metamorphic rocks and Carboniferous granite in the north and continues to the west of the studied area (Figure 3c). The eastern part of the study area is the Chiang Mai basin comprising various sediment of Ping River, such as gravel, sand, silt, clay, and mud. The Chiang Mai basin also has a massive pure limestone, "Mae On Permian limestone," in the eastern part. This limestone is similar to the Doi Chiang Dao limestone, a possible oceanic seamount origin [11]. 

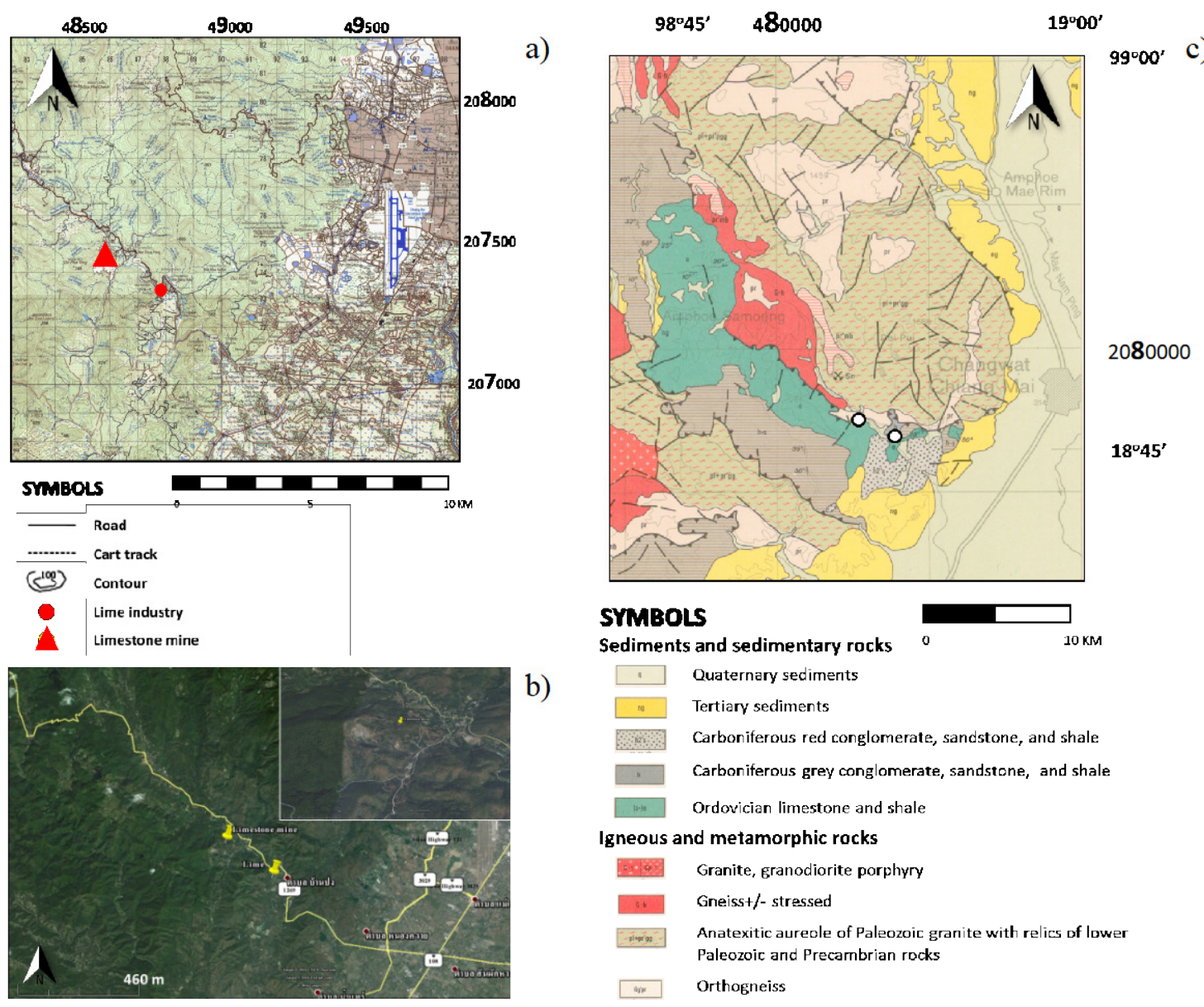

Figure 3 Location of the studied area; a) topographic map scale 1: 50,000 [7,8], b) satellite image $\left(\right.$ Google Earth $\left.\left.{ }^{\circledR}\right), c\right)$ geologic map of Chiang Mai Province scale 1: 250,000 [9].

\section{Materials and methodology}

The 8 samples were collected from 3 outcrops in the Ordovician rocks for the petrography analysis. Petrographically, the standard thin section of all the selected samples $(0.03 \mathrm{~mm}$ thick $)$ were prepared and studied at the Department of Geological Sciences, Faculty of Science, Chiang Mai University. The thin sections were studied to characterize mineral compositions, alterations, and textures by the polarized light microscope.

Petrography data for the geochemical analysis carefully selected 3 least-altered 3 samples. The major oxides $\left(\mathrm{SiO}_{2}, \mathrm{TiO}_{2}, \mathrm{Al}_{2} \mathrm{O}_{3}, \mathrm{Fe}\right.$ total as $\mathrm{Fe}_{2} \mathrm{O}_{3}, \mathrm{MnO}, \mathrm{MgO}, \mathrm{CaO}, \mathrm{Na}_{2} \mathrm{O}, \mathrm{K} 2 \mathrm{O}$, and $\left.\mathrm{P}_{2} \mathrm{O}_{5}\right)$ were measured by Phillip-MagixPro PW 2400 Wavelength Dispersive X-Ray Fluorescence (XRF) Spectrometer, fixed at the Department of Geological Sciences, Faculty of Science, Chiang Mai University. In addition, the loss on ignition (LOI) was analyzed by heating a platinum crucible that contained a $1.0 \mathrm{~g}$ sample in a furnace at $1,000^{\circ} \mathrm{C}$ for $12 \mathrm{~h}$. Powder samples of approximately $1.0 \mathrm{~g}$ must be weighed before and after heating for calculating LOI.

\section{Lithology and petrography}

The Ordovician rock samples are taken from the post-limestone quarry, showing a steep slope as a cliff (Figure 2). All samples react with dilute hydrochloric acid and show granoblastic texture with slight foliation, represented by black and white minerals. Under the microscope, these rocks show foliated texture and have a fine-grained texture (0.025- $0.3 \mathrm{~mm}$ across). The tiny calcite veins, approximately 1 $5 \mathrm{~mm}$ wide, are commonly present in the studied rocks.

According to petrographic data, the studied carbonate rocks can be defined as marble. These marbles mainly consist of calcite, with very small amounts of muscovite, quartz, talc, and opaque minerals (Figure 4). Some samples do not have any quartz and other silicate minerals such as mica, talc. 
The protolith of these marbles is high $\mathrm{Ca}^{2+}$ limestone, which may be metamorphosed in regional metamorphism and re-metamorphosed by contact metamorphism, as occurring typically around intrusive granitic rocks. High temperatures allow the atoms and ions in solid crystals to migrate, thus reorganizing the crystals, while high pressures cause the solution of the crystals at their point of contact within the rock. Thus the small calcite crystals in limestone change into larger crystals in marble.

a)

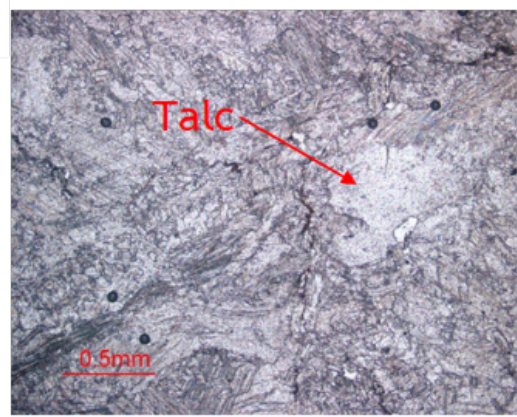

b)

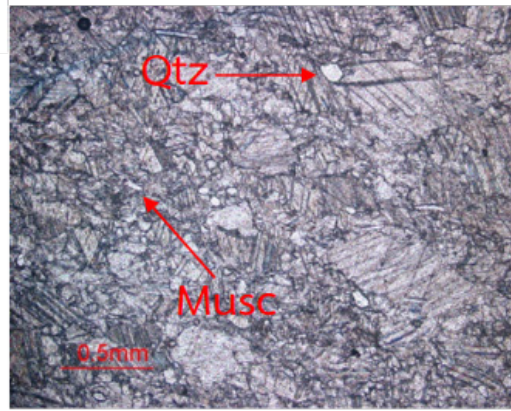

c)

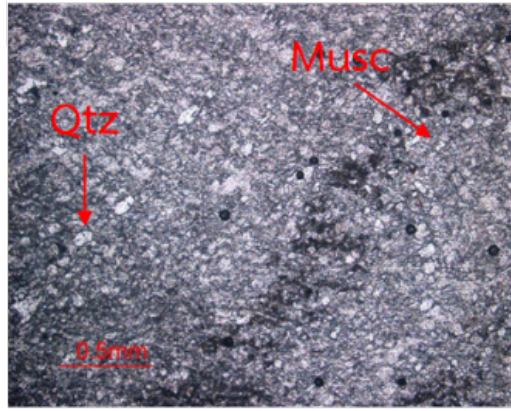

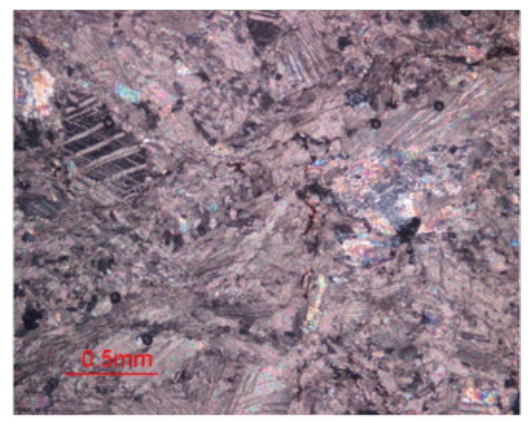
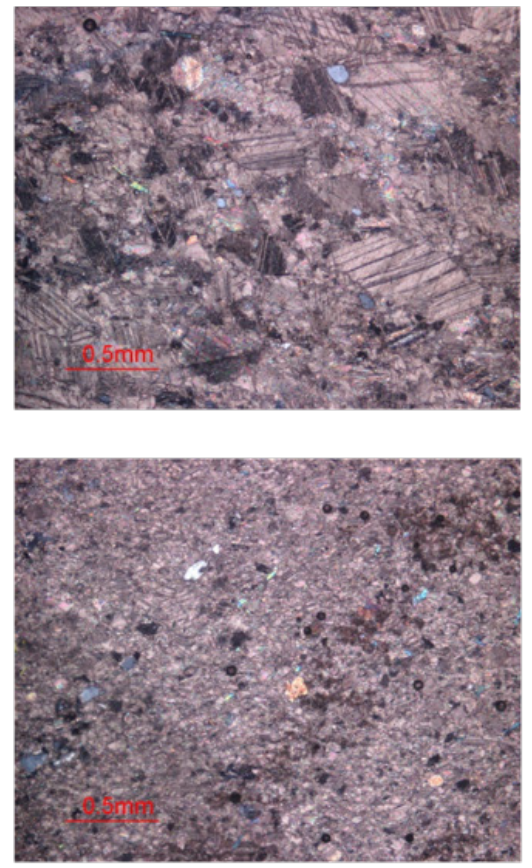

Figure 4 Photomicrographs of carbonate rocks in 3 areas diaplaying mineral compositions; a) LS1-1 in very steep cliff area, b) LS2-2 in post-mining area d) LS3-2 in gentle slope cliff area. Ordinary light (left), crossed polars (right); Talc $=$ Talc, Qtz $=$ quartz, Musc $=$ muscovite.

\section{Geochemistry and mineralogy}

Marble, the starting materials of the lime industry in the Ban Pong area, Chiang Mai Province, has a very high value of $\mathrm{CaO}$, with a small amount of $\mathrm{Fe}_{2} \mathrm{O}_{3}, \mathrm{MgO}, \mathrm{K}_{2} \mathrm{O}, \mathrm{Al}_{2} \mathrm{O}_{3}$ and $\mathrm{SiO}_{2}$ (Table1). Due to the ratio of ion agreeable with the ratio of its couple mineral, the chemical data accord to petrographic data presenting all of the mineral compositions. $\mathrm{Ca}^{2+}$ ion present in calcite mineral $\left(\mathrm{CaCO}_{3}\right)$, while $\mathrm{Mg}^{2+}$ ion is contained in the structure of dolomite mineral $\left(\mathrm{CaMg}\left(\mathrm{CO}_{3}\right)_{2}\right)$ and talc minerals $\left(\mathrm{Mg}_{3} \mathrm{Si}_{4} \mathrm{O}_{10}(\mathrm{OH})_{2}\right)$. $\mathrm{K}^{+}$ and $\mathrm{Al}^{3+}$ ions are filled in the structure of muscovite $\left(\mathrm{KAl}_{2}\left(\mathrm{AlSi}_{3} \mathrm{O}_{10}\right)(\mathrm{F}, \mathrm{OH})_{2}\right)$. Also, the $\mathrm{Si}^{4+}$ ion is the main component of quartz minerals $\left(\mathrm{SiO}_{2}\right)$. Moreover, $\mathrm{Fe}^{2+}$ and $\mathrm{Fe}^{3+}$ are indicated in opaque minerals, including magnetite $\left(\mathrm{Fe}_{3} \mathrm{O}_{4}\right)$ and hematite $\left(\mathrm{Fe}_{2} \mathrm{O}_{3}\right)$.

There is no standard to specify the $\mathrm{CaO}$ as 'available lime' by the British Standard Specification for Building Limes (BS 890: 1995). Instead, chemical quality is predicated mainly on the general $\mathrm{CaO}+$ $\mathrm{MgO}$ and the $\mathrm{CO}_{2}$ content, and the other volatiles. Calcium Lime 90 (CL 90) is the best example of limes, 
which be called 'high-calcium lime' with the chemical specification is $\mathrm{CaO}+\mathrm{MgO}>85 \%, \mathrm{MgO}<6 \%$, $\mathrm{CO}_{2}<6 \%$, and $\mathrm{SO}_{3}<2.5 \%$. Geochemistry data suggested the carbonate resources in this area have a high quality for producing lime with $97.3-97.9 \% \mathrm{CaO}$ and $0.1-0.3 \% \mathrm{MgO}$ [4], similar to Ordovician limestone in Thung Song, the southern part of Thailand (Table 1). However, the studied rocks contain higher $\mathrm{SiO}_{2}$ than Permian limestone, which are the primary resources for the lime industry, especially in Saraburi, Ratchaburi, and Chaiyaphum Provinces. This comparison suggests that the Ordovician marbles have other silicate minerals more than Permian limestone presenting by their geochemistry data, so it can save energy in the calcination process by decreasing decomposition temperature. Villagers use firewood to decline the chemical bonding of calcite in their wood-fire kiln to produce lime. The temperature and energy may be fit for the poly-phase composition of Ordovician marbles in this area.

Table 1 Whole-rock analyses of the studied rocks in the Ban Pong area and their comparison.

\begin{tabular}{|c|c|c|c|c|c|c|c|c|}
\hline \multirow{2}{*}{$\begin{array}{l}\text { Major } \\
\text { oxides }\end{array}$} & \multirow[b]{2}{*}{ LS1-1 } & \multirow[b]{2}{*}{ LS2-2 } & \multirow[b]{2}{*}{ LS3-2 } & \multicolumn{2}{|c|}{ Ordovician $^{*}$} & \multicolumn{3}{|c|}{ Permian $^{* *}$} \\
\hline & & & & $\begin{array}{l}\text { Thung } \\
\text { Song }^{\mathrm{a}}\end{array}$ & $\begin{array}{c}\text { Ko } \\
\text { Sichang }\end{array}$ & $\begin{array}{l}\text { Khao } \\
\text { Ngo }\end{array}$ & $\begin{array}{l}\text { Khao } \\
\text { Ngob }^{\text {a }}\end{array}$ & $\begin{array}{c}\text { Tuak Tham } \\
\text { Bunnak }^{\mathrm{a}}\end{array}$ \\
\hline $\mathrm{SiO}_{2}$ & 0.389 & 0.476 & 0.620 & 0.58 & 0.94 & 0.22 & 0.13 & 1.16 \\
\hline $\mathrm{TiO}_{2}$ & - & - & - & - & - & - & 0.01 & - \\
\hline $\mathrm{ZrO}_{2}$ & 0.019 & - & - & - & - & - & - & - \\
\hline $\mathrm{Al}_{2} \mathrm{O}_{3}$ & 0.154 & 0.122 & 0.167 & 1.36 & 0.31 & 0.06 & 0.34 & 0.26 \\
\hline $\mathrm{Fe}_{2} \mathrm{O}_{3} \mathrm{tt}$ & 0.309 & 0.376 & 0.392 & 0.16 & 0.84 & 0.27 & 0.05 & 0.55 \\
\hline $\mathrm{ZnO}$ & - & - & - & - & - & - & - & - \\
\hline SrO & 0.077 & 0.052 & 0.042 & - & - & - & - & - \\
\hline $\mathrm{BaO}$ & - & - & - & - & - & - & - & - \\
\hline MgO & 0.059 & 0.099 & 0.202 & 1.39 & 20.70 & 1.99 & 1.29 & 0.62 \\
\hline $\mathrm{CaO}$ & 55.483 & 56.520 & 55.998 & 53.26 & 31.36 & 54.46 & 54.76 & 54.70 \\
\hline $\mathrm{Na}_{2} \mathrm{O}$ & - & - & - & - & - & - & - & - \\
\hline $\mathbf{K}_{2} \mathbf{O}$ & 0.087 & 0.096 & 0.129 & - & - & - & - & - \\
\hline $\mathbf{P}_{2} \mathbf{O}_{5}$ & 0.143 & - & - & - & - & - & 0.01 & - \\
\hline LOI & 43.280 & 42.260 & 42.250 & 43.14 & 45.69 & 43.16 & 43.40 & 43.26 \\
\hline
\end{tabular}

${ }^{*}$ Kuentag, 1992, ${ }^{* *}$ Kuentag, 1983; a: Limestone, b: Dolomite

\section{Discussion}

Many lime industries are scattering in many places in Thailand, especially near Permian and Ordovician limestone mountains. The raw materials for lime production need high $\mathrm{CaO}$ raw materials derived from calcite crystal in the carbonate rocks, such as pure limestone, dolomitic limestone, chalk, marl, marble, and dolomite. Although pure limestone is a high-quality material, it needs high energy in the calcination process during manufacturing. Due to pure calcite have three-dimension cleavages, increasing temperature cause angle changes between $\mathrm{Ca}^{2+}$ and $\mathrm{CO}_{3}\left(\mathrm{CO}_{2}\right.$ reach out from the structure) and crystal destruction [12]. Calcium carbonate, or limestone, thermally decomposes (calcines) to calcium oxide by releasing carbon dioxide (Eq. (1)). The calcination reaction is reversible and endothermic (4.6 $\mathrm{MJ}$ heat required $/ \mathrm{kg}$ of quicklime produced) [3]. The other mineral compositions present in the Ordovician marbles at Ban Pong, Chiang Mai Province, made an impurity to raw materials before the calcination process, so temperature for the breaking down chemical bonding of calcite should be decreasing. 
Many companies and business sectors in Thailand always select Permian mountains that are pure limestone (non-silicates) to explore and manage mining activities. In Chiang Mai Province, the carbonate rocks are composed of Permian and Ordovician ages distributed around the region.

Nevertheless, Ban Pong people select the Ordovician marbles for producing the best lime of Chiang Mai by their primitive methods in the local kilns. The studied rocks show garnoblastic- and foliated texture and fine-grained crystals that suggest they are marble. According to their geochemistry data, these rocks are mainly composed of calcite, with a small amount of muscovite, quartz, talc, and opaque minerals. Therefore, the marbles in this area have high quality for producing lime, with $97.3-97.9 \%$ $\mathrm{CaO}$ and $0.1-0.3 \% \mathrm{MgO}$, based on the British Standard Specification for Building Limes (BS 890: 1995). The impurity by other minerals may be reducing the decomposition temperature in the calcination process [13]. So, these Ordovician marbles can make the people use firewood and reduce time and fuel compared with Permian pure limestone when they produce lime in their wood-fire kiln. Consequently, Ordovician marble has a suitable ratio of calcite and other minerals, which is the perfect raw material for lime production by primitive methods with their local kilns.

\section{Conclusion and recommendation}

Lime in Ban Pong, Hang Dong District, Chiang Mai Province was produced by the traditional method by local people. The carbonate raw materials, which are the Ordovician marble, were carried from the post-mining area. These rocks show granoblastic texture with slight foliation that can be defined as marble. These marbles are made up mainly of calcite with a small amount of quartz, muscovite, talc, and opaque minerals, according to the value of $\mathrm{CaO}, \mathrm{SiO}_{2}, \mathrm{Al}_{2} \mathrm{O}_{3}, \mathrm{~K} 2 \mathrm{O}$, and $\mathrm{Fe}_{2} \mathrm{O}_{3}$ in whole-rock analysis by XRF. The protolith of this studied rock is high $\mathrm{Ca}^{2+}$ limestone that was metamorphosed by regional metamorphism and igneous intrusion. These marbles are suitable to produce the lime with $97.3-97.9 \%$ $\mathrm{CaO}$ and $0.1-0.3 \% \mathrm{MgO}$, interpreting by geochemistry data from XRF analysis with a loss on ignition similar to a lime. The geochemical characteristics of these marbles suggest that they have a high calcite ratio which is advantageous for breaking downstage in the calcination process, and their impurity reduced the decomposition temperature. So, these Ordovician marbles are the appropriate raw material for traditional lime manufacture, producing high-quality lime based on the British Standard Specification for Building Limes.

\section{Acknowledgment}

This work was supported by Igneous Rocks and Related Ore Deposits Research Laboratory (IROL) of the Department of Geological Sciences, Faculty of Science, Chiang Mai University. Also, thanks to Mr. Chanakan Boonnawa for his help in fieldwork and sample preparation.

\section{References}

[1] MM Miller. Lime. In: MM Miller (Ed.). Minerals Yearbook. USGS Mineral Resources Program, United States Geological Survey, Washington DC, 2007, p. 43.

[2] National Lime Association. LIME: The essential chemical. National Lime Association, Virginia, 2007, p. 9.

[3] JAH Oates. Lime and limestone-chemistry and technology, production and uses. Wiley-VCH Verlag GmbH, Weinem, Germany, 1998, p. 455.

[4] M Hassibi. Factors affecting the quality of quicklime (CaO) from mining to manufacturing to usage. Chemco Systems L.P., Pennsylvania, 2009, p. 7.

[5] C Kuentag. Limestone of Thailand. Department of Mineral Resources, Bangkok, Thailand, 1983, p. 27.

[6] C Kuentag. Limestone resources and development in Thailand. Department of Mineral Resources, Bangkok, Thailand, 1992, p. 12.

[7] Royal Thai Survey Department. Topographic map Amphoe San Pa tong, sheet 4746II, scale 1: 50,000. Royal Thai Survey Department, Bangkok, Thailand, 1999.

[8] Royal Thai Survey Department. Topographic map Chiang Mai Province, sheet 4746I, scale 1: 50,000. Royal Thai Survey Department, Bangkok, Thailand, 1999.

[9] F Baum, EV Braun, A Hess, KE Koch, G Kruse, H Quarch and M Siebenhuner. On the geology of Northern Thailand. Beihefte Geologische Jahrbunch, Hanover, Germany, 1970, p. 23.

[10] F Baum, EV Braun, A Hess and KE Koch. Geologic map of Changwat Chiang Mai, scale 1:250000. Department of Mineral Resources, Bangkok, Thailand, 1982. 
[11] K Ueno. Gondwana/Tethys divide in East Asia: Solution from Late Paleozoic foraminiferal paleobiogeograpgy. In: Proceedings of the International Symposium on Shallow Tethys 5, Chiang Mai, Thailand. 1999, p. 45-54.

[12] N Ishizawa, H Setoguchi and K Yanagisawa. Structural evolution of calcite at high temperatures: Phase V unveiled. Sci. Rep. 2013; 3, 2832.

[13] British Standards Institution. Specification for building limes. British Standards Institution, London, 1995, p. 24. 